\title{
KOMBINASI ASAP CAIR TONGKOL JAGUNG (Zea mays L.) DAN SARI LEMON CUI (Citrus microcarpa) DALAM MENGHAMBAT PEMBENTUKAN PEROKSIDASI LIPID
}

\author{
Chesya Hana Sersermudy ${ }^{1 *}$, Edi Suryanto ${ }^{1}$ dan Julius Pontoh ${ }^{1}$ \\ ${ }^{1}$ Jurusan Kimia Fakultas Matematika dan Ilmu Pengetahuan Alam Universitas Sam Ratulangi, \\ Jl. Kampus Unsrat, Kleak, Manado 95115 Sulawesi Utara
}

\begin{abstract}
ABSTRAK
Penelitian ini bertujuan untuk mempelajari kombinasi asap cair tongkol jagung dan sari lemon cui dalam menghambat pembentukkan peroksidasi lipid. Penelitian ini menggunakan metode untuk menganalisis kandungan total fenolik, penangkal radikal bebas (DPPH), uji vitamin $\mathrm{C}$ dan peroksidasi lipid dengan menggunakan spektrofotometer UV-Vis. Hasil penelitian menunjukkan kandungan total fenolik dari kombinasi asap cair tongkol jagung dan sari lemon $\mathrm{F} 1(57,94 \mu \mathrm{g} / \mathrm{mL}), F 2(82,21 \mu \mathrm{g} / \mathrm{mL}), \mathrm{F} 3(77,85 \mu \mathrm{g} / \mathrm{mL}) \mathrm{F} 4(59,94 \mu \mathrm{g} /$ $\mathrm{mL}$ ) dan F5 $(93,94 \mu \mathrm{g} / \mathrm{mL})$. Penangkal radikal bebas (DPPH) kombinasi asap cair tongkol jagung dan sari lemon cui F1 $(78,20 \%)$, F2 $(68,76 \%)$, F3 $(73,93 \%)$ F4 $(75,10 \%)$ dan F5 $(65,75 \%)$. Kandungan vitamin C dari kombinasi asap cair tongkol jagung dan sari lemon cui F2 $(73,04 \mu \mathrm{g} / \mathrm{mL}), \mathrm{F} 3(25,25 \mu \mathrm{g} / \mathrm{mL}), \mathrm{F} 4(183,04 \mu \mathrm{g} / \mathrm{mL})$ dan F5 $(292,16 \mu \mathrm{g} / \mathrm{mL})$. Kombinasi dari asap cair tongkol jagung dan sari lemon cui dalam penghambat pembentukkan peroksidasi lipid pada ikan cakalang dengan konsentrasi 10\% tanpa kombinasi asap cair tongkol jagung dan sari lemon cui menunjukkan peroksidasi lipid yang tinggi yaitu 1,217 dalam empat hari. Kombinasi asap cair tongkol jagung dan sari lemon cui mengandung fenolik yang bertindak sebagai antioksidan dan dapat menghambat peroksidsi lipid pada ikan cakalang.
\end{abstract}

Kata kunci: Asap cair, tongkol jagung, sari lemon cui, peroksidasi lipid

\section{ABSTRACT}

Sersermudy et al., 2019. This research aims to study a combination of corncob liquid smoke and cui lemon juice in inhibiting the formation of lipid peroxidation. This research used a method to analyze the content of total phenolic, free radicidal (DPPH), vitamin C and lipid peroxidation using a UV-Vis spectrophotometer. The results showed a combination of total phenolic from a combination of corncobs and lemon juice F1 57.94 F2 82.21 F3 77.85 F4 59.94 and F5 $93.94 \mu \mathrm{g} / \mathrm{mL}$. Free radical scavenging (DPPH) a combination of liquid corncob and lemon juice cui F1 (78.20\%), F2 (68.76\%) F3 (73.93\%), F4 (75.10\%) and F5 (65.75\%). Vitamin C content from a combination of liquid corncob smoke and lemon juice cui F2 $(73.04 \mu \mathrm{g} / \mathrm{mL}), \mathrm{F} 3(125.25 \mu \mathrm{g} / \mathrm{mL})$ F4 $(183.04 \mu \mathrm{g} / \mathrm{mL})$ and F5 $(292.16 \mu \mathrm{g} / \mathrm{mL})$. The combination of corncob liquid smoke and cui lemon juice in the formation of lipid peroxidation in $10 \%$ of skipjack tuna without the combination of corn cob liquid smoke and cui lemon juice showed high lipid peroxidation of 1.217 in four days. The combination of corncob liquid smoke and lemon cui juice contains phenolic which acts as an antioxidant and can inhibit lipid peroxidation in skipjack.

Keywords: Liquid smoke, corncob, cui lemon juice, lipid peroxidation

\section{PENDAHULUAN}

Jagung (Zea mays L.) adalah komoditi unggulan tanaman pangan dunia yang terpenting selain gandum dan padi. Penggunan tanaman jagung akhir-akhir ini semakin meningkat, dikarenakan pemanfaatan jagung yang tidak terbatas pada salah satu jenis komoditi menyebabkan meningkatnya jumlah limbah tongkol jagung. Salah satu sektor yang belum banyak dimanfaatkan adalah limbah pertanian. Limbah pada dasarnya adalah suatu bahan yang tidak dipergunakan kembali dari hasil aktivitas manusia ataupun proses-proses alam yang

Korespondensi :

Telepon: +62 81- 458- 5781

Email: chesya.hana@gmail.com

DOI: https://doi.org/10.35799/cp.12.1.2019.27298 belum mempunyai nilai ekonomis, bahkan mempunyai nilai ekonomis yang sangat kecil (Mongan dkk., 2011). Pemanfaatan limbah merupakan salah satu alternatif untuk menaikan nilai ekonomi limbah tersebut, salah satunya adalah limbah tongkol jagung dari hasil buangan pengoalahan jagung pipilan.

Asap cair hasil pirolisis mengandung kelompok senyawa fenol, asam dan karbonil dan dapat berperan sebagai antimikroba, antioksidan dan memberi efek warna, cita rasa khas asap pada produk asapan (Girard, 1992). Menurut Purba dkk. (2006) dan Halim dkk., (2005), asap cair dari cangkang sawit memiliki 
komponen fenol 56,53 \% , asam asetat 29,97\%, 2-metil fenol 8,850\%, 2-metoksi fenol 9,350\%, 2-metoksi-4-metil fenol 11,317\%, 4-etil-2metoksi fenol $12,742 \%$ dan 2,6 dimetoksi fenol $13,708 \%$.

Lemon cui (Citrus microcarpa) dengan sebutan lain adalah lemon ikan atau lemon kalamansi merupakan sejenis jeruk lokal yang banyak tumbuh di Sulawesi Utara. Lemon cui banyak digunakan untuk menghilangkan bau amis pada ikan dan campuran bumbu masakan pada kuliner tradisonal serta memberi aroma penggugah selera makan. Selain itu, lemon cui memiliki komponen fitokimia yang penting terutama kandungan vitamin $\mathrm{C}$ yang dapat berfungsi sebagai antioksidan. Vitamin $\mathrm{C}$ selain berfungsi sebagai antioksidan yang melindungi kulit dari pengaruh radikal bebas dan dapat juga memperkuat sel-sel kulit serta meningkatkan produksi kolagen pada kulit sehingga elastisitas kulit tertap terjga (Kumalaningsih, 2006). Beberapa penelitian menyatakan bahwa pisang goroho direndam dalam air perasan lemon cui memiliki aktivitas antioksidan lebih tinggi bila dibandingkan dengan tanpa perendaman (Kiay dkk., 2011). Penelitian lain dilakukan oleh Suryanto dkk. (2011) menyatakan bahwa perendaman pisang goroho dalam lemon kalamansi memiliki kadar fenolik $(55,82 \mathrm{mg} / \mathrm{kg})$ dan asam askorbat yang tinggi $(51,92 \mathrm{mg} / \mathrm{kg})$.

Penggunaan kombinasi antara asap cair dan lemon cui dapat memberikan variasi pada citra rasa dan aroma tetapi juga meningkatkan kandungan fitokimia dan potensi antioksidannya. Penambahan lemon cui pada asap cair diharapkan juga dapat mengurangi bau menyengat asap cair dan meningkatkan kandungan bioaktif dari campuran tersebut. Selain itu, kombinasi asap cair dan sari lemon cui dapat memberikan efek sinergis dalam menghambat pembentukkan reaksi oksidasi pada bahan pangan yang kaya kandungan asam lemak tak jenuh seperti pada lipid ikan.

Penggalian tentang pemanfaatan asap cair dan lemon cui yang sudah diketahui pemanfaatannya dengan melakukan kombinasi dua jenis bagian tanaman dimana masingmasing bagian tanaman tersebut sudah banyak dimanfaatkan oleh masyarakat luas dalam pengawetan, citra rasa dan aroma.

Penelitian ini bertujuan untuk menentukan potensi antikosidan dan penghambatan pembentukkan peroksidasi lipid dari kombinasi asap cair tongkol jagung dan ekstrak lemon cui.

\section{BAHAN DAN METODE}

\section{Bahan dan alat}

Bahan yang digunakan adalah kombinasi asap cair dan sari lemon cui dengan konsentrasi masing-masing 0\%, 25\%, 50\%, 75\% dan $100 \%$. Tongkol jagung jenis Manado kuning, ikan cakalang, lemon cui, reagen Folin-Ciocalteu $50 \%$, akuades, $\mathrm{Na}_{2} \mathrm{CO}_{3} 2 \%$, larutan $\mathrm{DPPH}$, buffer fosfat ( $1 \mathrm{~mL}, 0,2 \mathrm{M}, \mathrm{pH}$ 7), $1 \mathrm{~mL}$ kalium ferisianat $1 \%, 1 \mathrm{~mL}$ asam trikloroasetat, 0,5 $\mathrm{mL}$ besi (III) klorida $0,1 \%, 2 \mathrm{~mL}$ amilum $2 \%$, Iodium $0,01 \mathrm{~N}$, TBA $0,02 \mathrm{M}$ dan TCA $10 \%$. Alat yang digunakan yaitu vortex, alat-alat gelas, mikropipet, oven, reaktor pirolisis, kertas saring, plastik cling wrap, timbangan analitik, alumunium foil, Sonikator (Krisbow $40 \mathrm{KHz}$ ), sudip, batang pengaduk, water bath dan spektrofotometer UV-Vis dan lemari pendingin.

\section{Preparasi sampel}

Buah lemon cui terlebih dahulu dibersihkan kemudian dipotong dan setelah itu buah lemon cui tersebut diperas dan disaring sehingga diperoleh sari buah lemon cui. Sari lemon cui selanjutnya disimpan pada suhu $5{ }^{\circ} \mathrm{C}$ sebelum digunakan.

\section{Pembuatan asap cair}

Tongkol jagung sebanyak satu kilogram dimasukkan ke dalam reaktor pirolisis yang dilengkapi dengan rangkaian kondensasi dan kondensor pendingin. Proses pirolisis dilakukan pada suhu $400{ }^{\circ} \mathrm{C}$ selama 60 menit dan kondensasi diakhiri sampai tidak ada asap cair yang menetes dalam penampung. Asap cair yang diperoleh, disimpan selama 7 hari pada suhu kamar untuk memisahkan endapan dengan supernatant.

\section{Pembuatan kombinasi asap cair tongkol jagung dan sari lemon cui}

Pembuatan kombinasi asap cair dan sari lemon cui dibuat dengan lima kombinasi, dimana kelima kombinasi tersebut dibuat dalam formulasi yang berbeda. Asap cair tongkol jagung dan sari lemon cui dicampur dengan komposisi sesuai dengan perlakuan dengan menggunakan alat sonikator pada suhu kamar selama 15 menit. Rancangan kelima formulasi kombinasi dalam penelitian ini dapat dilihat pada Tabel 1. 
Tabel 1. Komposisi (\%v/v) dari formulasi kombinasi asap cair tongkol jagung dan sari lemon cui

\begin{tabular}{lccccc}
\hline & F1 & F2 & F3 & F4 & F5 \\
\hline Asap cair & 100 & 75 & 50 & 25 & 0 \\
Sari lemon cui & 0 & 25 & 50 & 75 & 100 \\
\hline
\end{tabular}

Kelima formulasi yang dihasilkan dianalisis kandungan total fenolik, aktivitas penangkal radikal bebas, daya reduksi, uji kandungan vitamin $\mathrm{C}$ dan penghambatan peroksidasi lipid pada daging ikan cakalang.

\section{Penentuan kandungan total fenolik}

Kandungan total fenolik ditentukan menggunakan metode Jeong dkk. (2004). Sebanyak $0,1 \mathrm{~mL}$ larutan masing-masing sampel dimasukkan ke dalam tabung reaksi, lalu ditambahkan $0,1 \mathrm{~mL}$ reagen Folin Ciocalteu $50 \%$ dalam tabung reaksi dan kemudian campuran divortex selama 3 menit. Setelah interval waktu 3 menit, ditambahkan $2 \mathrm{~mL}$ larutan $\mathrm{Na}_{2} \mathrm{CO}_{3} 2 \%$, kemudian campuran diinkubasi dalam ruang gelap selama 30 menit. Selanjutnya dibaca absorbansinya pada $\lambda 750$ $\mathrm{nm}$ dengan menggunakan spektrofotometer UVVis. Hasilnya diplotkan terhadap kurva standar asam galat yang dipersiapkan dengan cara yang sama.

\section{Uji aktivitas penangkal radikal bebas DPPH}

Penentuan aktivitas penangkal radikal bebas ditentukan dengan metode Burda \& Oleszeck (2001). Sebanyak 0,5 mL sampel masing-masing ditambahkan $1,5 \mathrm{~mL}$ larutan DPPH (2,2-difenil-1-pikrilhidrazil) dan divorteks selama 2 menit. Berubahnya warna larutan dari ungu ke kuning menunjukkan efisiensi penangkal radikal bebas. Selanjutnya pada 5 menit terakhir menjelang 30 menit inkubasi absorbansinya diukur pada panjang gelombang $517 \mathrm{~nm}$ dengan menggunakan spektofotometer UV-Vis. Persentase aktivitas penangkal radikal bebas (APRB) dengan rumus:

$$
\text { APRB }=1-\frac{\text { A sampel }}{\text { A kontrol }} \times 100 \%
$$

Keterangan: A kontrol $=$ absorbansi sampel, $\mathrm{A}$ sampel $=$ absorbasi kontrol

\section{Penentuan kandungan vitamin $\mathrm{C}$}

Kandungan vitamin $\mathrm{C}$ ditentukan dengan metode titrasi (Jacobs, 1987). Dipipet $5 \mathrm{~mL}$ kombinasi asap cair dan sari buah lemon cui dan dimasukkan ke dalam Erlemeyer $100 \mathrm{~mL}$. ditambahkan $2 \mathrm{~mL}$ amilum 2\%. Kemudian dititrasi dengan larutan standar Iodium 0,01 N ( 2-2,5 gram KI dan 1,296 gram $\mathrm{I}_{2}$ dilarutkan dalam aquades sampai 1 liter). Perhitungan kandungan vitamin $\mathrm{C}$ menggunakan rumus:

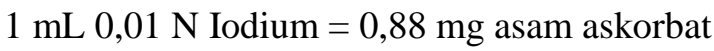

\section{Penentuan peroksidasi lipid daging ikan cakalang}

Sebanyak $50 \mathrm{~g}$ (tebal $1 \mathrm{~cm}$ ) ikan cakalang direndam dalam asap cair dengan konsentrasi masing-masing $0,25,50,75$ dan $100 \%$ selama 30 menit. Selanjutnya dimasukkan ke dalam plastik cling wrap dan disimpan selama 4 hari pada suhu $5{ }^{\circ} \mathrm{C}$, selang waktu dua hari sampel diambil untuk diperiksa angka asam tioribarbiturat (TBA) pada panjang gelombang $532 \mathrm{~nm}$.

\section{Penentuan angka TBA}

Penetuan angka TBA pada sampel dilakukan dengan metode Shahidi dan Hong (1991) dengan sedikit modifikasi. $1 \mathrm{~g}$ sampel ikan cakalang dimasukkan dalam tabung reaksi dan ditambahkan dengan 2,5 mL TCA $10 \%$ $/(\mathrm{w} / \mathrm{v})$, divortek Selama 1 menit, lalu disentifugasi selama 5 menit. Supernatant yang diperoleh kemudian dimasukkan dalam tabung ulir, ditambah $2,5 \mathrm{~mL}$ TBA $0,02 \mathrm{M}$, divortek selama 1 menit, lalu dipanaskan dalam water bath selama 15 menit pada suhu $100^{\circ} \mathrm{C}$. campuran kemudian didinginkan pada suhu kamar dan disentrifugasi kembali 15 menit. Campuran yang berwarna merah muda tersebut diukur absorbansinya pada $\lambda 532 \mathrm{~nm}$. Angka TBA akan diperoleh dengan mengalikan hasil absorbansi sampel dengan konstanta yang diperoleh dari standar.

\section{HASIL DAN PEMBAHASAN}

Dalam penelitian ini, limbah Tongkol jagung sebanyak $1 \mathrm{~kg}$ yang dipirolisis menghasilkan asap cair $500 \mathrm{~mL}$ yang telah disimpan selama 7 hari untuk memisahkan endapan dan supernatan. Kemudian supernatan yang berwanrna coklat disaring sebanyak 200 $\mathrm{mL}$ lalu dilakukan proses destilasi pada suhu $100{ }^{\circ} \mathrm{C}$ yang berlangsung selama 3 jam dan mendapatkan hasil destilat I sebanyak $138 \mathrm{~mL}$ berwarna kuning. Kemudian disaring lagi sebanyak $200 \mathrm{~mL}$ proses destilasi fraksinasi dengan kolom vigreoux pada suhu $100{ }^{\circ} \mathrm{C}$ yang 
berlangsung selama 3 jam dan mendapatkan hasil destilat II sebanyak $135 \mathrm{~mL}$ berwarna kuning pucat.

\section{Kandungan total fenolik dan vitamin C kombinasi asap cair dan sari lemon cui}

Senyawa fenolik merupakan metabolit sekunder yang dihasilkan tanaman yang memiliki fungsi sebagai antioksidan dan penangkal radikal bebas. Penentuan kandungan total fenolik dalam kombinasi asap cair dan ekstrak lemon cui dengan konsentrasi $0 \%, 25 \%, 50 \%, 75 \%$ dan $100 \%$. Asam Galat merupakan acuan umum untuk mengukur sejumlah senyawa fenolik yang terdapat dalam suatu bahan (Mongkolsip dkk., 2004). Penggunaan asam galat sebagai standar dikarenakan senyawa asam galat mempunyai gugus hidroksil dan ikatan rangkap yang terkonjugasi pada masing-masing cincin benzene yang menyebabkan senyawa ini sangat efektif untuk membentuk senyawa kompleks dengan reagen Folin-Ciocalteu, sehingga reaksi yang terjadi lebih sensitif dan intensif (Julkunen-Tito, 1985).

Tabel 2. Kandungan total fenolik dan kandungan vitamin C dari kombinasi asap cair dan sari lemon cui.

\begin{tabular}{ccc}
\hline Sampel & $\begin{array}{c}\text { Kandungan } \\
\text { total fenolik } \\
(\mu \mathrm{g} / \mathrm{mL})\end{array}$ & $\begin{array}{c}\text { Kandungan } \\
\text { vitamin C } \\
(\mu \mathrm{g} / \mathrm{mL})\end{array}$ \\
\hline F1 & $57,94 \pm 2,31^{\mathrm{a}}$ & - \\
$\mathrm{F} 2$ & $82,21 \pm 0.39^{\mathrm{b}}$ & $73,04 \pm 0,03^{\mathrm{a}}$ \\
F3 & $77,85 \pm 3,21^{\mathrm{b}}$ & $125,25 \pm 0,07^{\mathrm{b}}$ \\
F4 & $59,94 \pm 0,77^{\mathrm{a}}$ & $183,04 \pm 0,10^{\mathrm{c}}$ \\
F5 & $93,94 \pm 2,31^{\mathrm{c}}$ & $292,16 \pm 0,26^{\mathrm{d}}$ \\
\hline
\end{tabular}

Berdasarkan Tabel 2, dapat diketahui bahwa kandungan total fenolik dalam kombinasi asap cair dan sari lemon cui F1 (0\%) sebesar $57,94 \mu \mathrm{g} / \mathrm{mL}$, dan kandungan fenolik tertinggi yaitu F5 (100\%) 93,94 $\mu \mathrm{g} / \mathrm{mL}$. Hasil statistika menunjukkan bahwa terdapat perbedaan nyata kandungan total fenolik pada masing-masing konsentrasi kombinasi asap cair dan sari lemon cui. Hal ini dikarenakan kombinasi asap cair dan ekstrak lemon cui dapat bereaksi dengan asam fosfomolibdat-fosfotungstat dalam reagen FolinCiocalteu (kuning) yang mengalami perubahan warna menjadi biru. Semakin tua intensitas warna larutan menunjukkan total senyawa fenolik dalam kombinasi asap cair dan sari lemon cui semakin besar. Senyawa antioksidan mampu bertindak sebagai penyumbang radikal hydrogen atau dapat bertindak sebagai aseptor radikal bebas sehingga dapat menunda proses oksidasi (Frankel, 2005).

Berdasarkan Tabel 2 kandungan vitamin $\mathrm{C}$ tertinggi Hasil uji lanjut Duncan terhadap total fenol masing-masing kombinasi diketahui bahwa F5 $(100 \%)$ memberikan perbedaan nyata terhadap F1 (0\%), F2 (25\%), F3 (50\%) dan F5 (75\%). Perbedaan nyata dimaksud adalah kadar kandungan vitamin $\mathrm{C}$ dimana urutannya secara berturut-turut adalah F5 (100\%) lebih besar dari $\mathrm{F} 2$ (25\%), F3 (50\%), F4 (75\%) dan F1 (0\%). Hasil uji statistik didapatkan bahwa terdapat perbedaan yang nyata kandungan vitamin $C$ pada masing-masing kombinasi $(\mathrm{p}<0,05)$. Dengan demikian semakin besar konsentrasi maka kemampuan antioksidan vitamin $\mathrm{C}$ untuk mencegah kerusakan lipida semkin bagus. Dengan adanya kandungan vitamin $\mathrm{C}$ maka dapat mencegah dan memperlambat terjadinya proses oksidasi lipid pada daging ikan cakalang. Hal ini disebabkan asam lemak hasil hidrolisis lemak mudah mengalami oksidasi dan apabila terjadi kontak dengan oksigen akan menghasilan hidroperoksida. Menurut Raharjo (2006) menyatakan bahwa hidroperoksida selanjutnya mengalami pemecahan menjadi aldehid dan keton yang dapat menyebabkan ketengikan. Oleh karena itu, dengan adanya antioksidan maka dapat digunakan untuk menghambat terjadinya proses oksidasi lipida.

\section{Aktivitas penangkal radikal DPPH kombinasi asap cair dan sari lemon cui}

Efek dari kombinasi asap cair dan ekstrak lemon cui terhadap aktivitas penangkal radikal bebas disajikan pada Gambar 1. Dari data tersebut menunjukkan bahwa aktivitas penangkal radikal bebas pada konsentrasi $0 \%$ yang lebih tinggi dibandingkan $100 \%$ sari lemon cui.

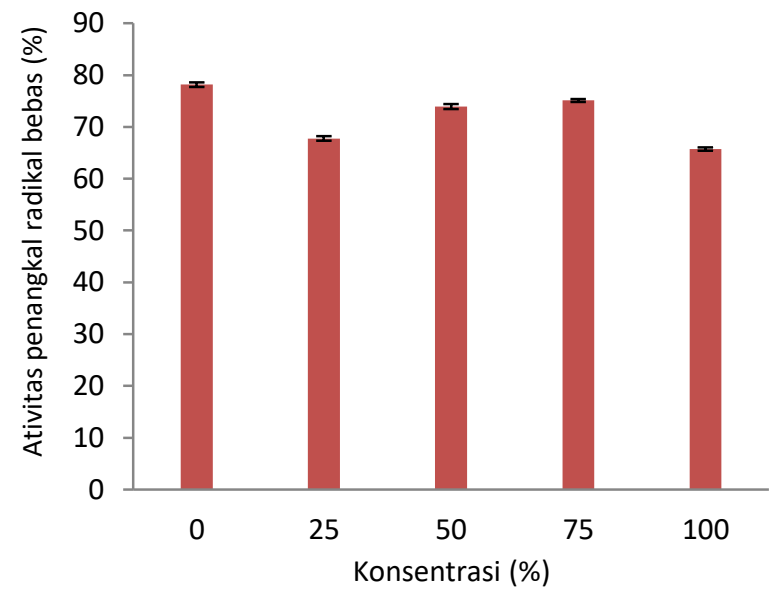

Gambar 1. Aktivitas penangkal radikal DPPH dari kombinasi asap cair dan sari lemon cui 
Gambar 1 menunjukkan bahwa F1 memiliki penangkal radikal bebas paling tinggi dengan presentase sebesar $(78,20 \%)$, yang berbeda nyata dengan F5 $(65,75 \%), \mathrm{F} 4(75,10 \%)$, F3 $(73,93 \%)$, dan F2 (68,76\%). penangkal radikal bebas menunjukkan bahwa F1 memiliki nilai penangkal radikal bebas yang tinggi. Penurunan aktivitas ekstrak lemon cui sebagai akibat dari adanya interferensi warna dari kombinasi asap cair dan ekstrak lemon cui dengan warna DPPH yaitu warna ungu ke warna kuning. Hal ini mengakibatkan analisis pembacaannya tidak menggambarkan aktivitas antioksidan yang sesungguhnya. Semakin tinggi konsentrasi dari kombinasi asap cair dan sari lemon cui maka warna larutan menjadi semakin kuning. Akibatnya absorbansi yang terbaca tinggi dan aktivitas yang diperoleh menjadi rendah. Penurunan intensitas warna ini terjadi karena penambahan hidrogen dari senyawa fenolik pada elektron yang tidak berpasangan pada radikal nitrogen dalam struktur senyawa DPPH (Suryanto, 2012). Semkin cepat turun nilai absorbansi atau semakin cepat perubahan warna dari larutan berarti semakin berpotensi sebagai penangkal radikal bebas (Yen \& Duh, 1994; Yen \& Chen, 1995). Aktivitas penangkapan radikal bebas umumnya naik dengan penambahan konsentrasi tertentu, kemudian aktivitasnya akan turun dengan penambahan konsentrasi yang lebih besar (Lai dkk., 2001).Menurut Shahidi dan Wanasundara (2002), penangkal radikal bebas yang beraksi dengan radikal peroksil sebelum asam lemak tak jenuh rantai panjang bereaksi dengan radikal peroksil, dapat berperan sebagai antioksidan dan mencegah oksidasi lipida. Pengujian ini dilakukan untuk membandingkan aktivitas penangkapan radikal bebas DPPH dari kombinasi asap cair dan sari lemon cui menggunakan metode Gaulejac dkk. (1998) yang dimodifikasi.

\section{Aktivitas peroksidasi lipid terhadap daging ikan cakalang}

Aktivitas ekstrak kombinasi asap cair dan sari lemon cui dalam menghambat kerusakan daging ikan cakalang $10 \%$ dan daging ikan emas $10 \%$ pada suhu $5^{\circ} \mathrm{C}$ selama penyimpanan 4 hari dengan 2 konsentrasi yang berbeda dapat dilihat pada Gambar 2. Berdasarkan gambar terlihat bahwa daging ikan cakalang yang ditambahkan dengan kombinasi asap cair dan sari lemon cui dengan konsentrai $10 \%$ menunjukkan kenaikkan konsentrasi MDA yang lebih rendah dibandingkan kontrol suhu $5^{0} \mathrm{C}$ hal ini menunjukkan Peningkatan intensitas warna merah hasil reaksi menunjukkan peningkatan kerusakan oksidasi bahan pangan (Ramanathan \& Das, 1992). Malonaldehida adalah senyawa yang bereaksi dengan TBA menghasilkan larutan berawarna merah, diukur intensitasnya pada panjang gelombang $532 \mathrm{~nm}$. Kombinasi asap cair dan sari lemon cui yang diaplikasikan pada ikan cakalang $10 \%$ dan ikan emas $10 \%$ memiliki aktivitas antioksidatif. Hasil ini sesuai dengan penelitian Suryanto (2007), selama penyimpanan pada kontrol ikan emas meningkatkan konsentrasi MDA secara signifikan, sedangkan pada konsentrasi $10 \%$ ikan cakalang meningkat namun tidak signifikan pada ikan mas $10 \%$ $(p<0,05)$.

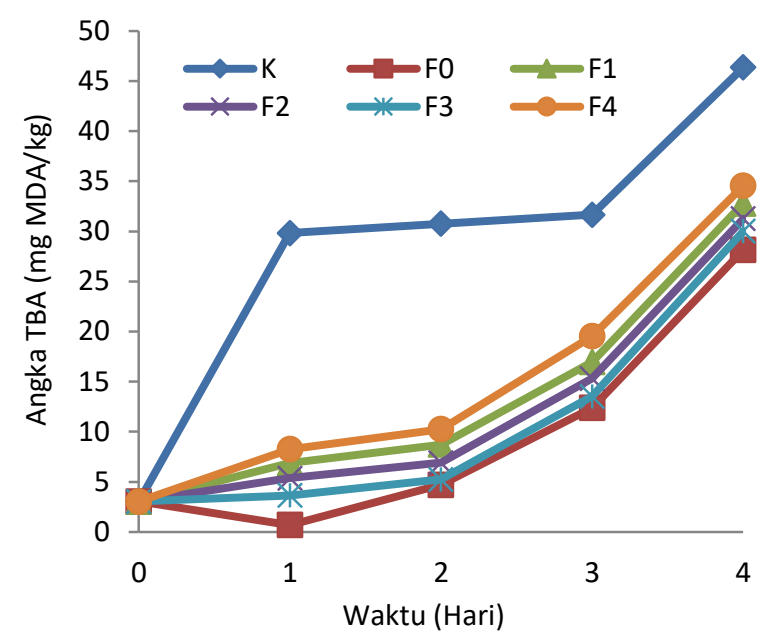

Gambar 2. Aktivitas kombinasi asap cair dan sari lemon cui pada berbagai konsentrasi $10 \%$ terhadap angka TBA daging ikan cakalang mentah pada suhu $5^{\circ} \mathrm{C}$ selama penyimpanan 4 hari.

Selain itu, dari data tersebut dapat dilihat bahwa aktivitas kombinasi asap cair dan sari lemon cui pada daging ikang cakalang mentah meningkat dari konsentrasi $75 \%$ hingga $0 \%$. hal ini menunjukkan bahwa semakin tinggi konsentrasi kombinasi asap cair dan ekstrak lemon cui tinggi pula aktivitas kombinasi asap cair dan ekstrak lemon cui tersebut sebagai antioksidan. Besarnya angka TBA dinyatakan sebagai mg MDA per kg sampel dan dihitung dengan cara mengalikan hasil absorbansi MDA dengan konstanta yang didapatkan dari penggunaan precursor standar MDA, seperti 1,1,3,3-tetrametoksipropana (TMP) (Shahidi dan Hong, 1991). Semakin besar absorbansi yang terukur, semakin besar pula angka TBA yang didapatkan. Dengan demikian besarnya angka TBA berbanding lurus dengan banyaknya produk 
hasil oksidasi lemak bahan alam.Hasil analisis Duncan menunjukkan bahwa F0 memiliki perbedaan nyata $(\mathrm{p}<0,05)$ terhadap $\mathrm{F} 4, \mathrm{~F} 3, \mathrm{~F} 2, \mathrm{~F} 1$, dan $\mathrm{K}$. uji beda nyata menunjukkan $\mathrm{K}, \mathrm{F} 4, \mathrm{~F} 1$ dan $\mathrm{F} 2, \mathrm{~F} 3$ dan $\mathrm{F} 4$ tidak berbeda nyata $(\mathrm{p}>0,05)$. Berdasarkan perhitungan MDA untuk masingmasing konsentrasi, dimana angka TBA sampel dari yang paling tinggi hingga paling rendah secara berurutan sebagai berikut $\mathrm{K} ; 0 \% ; 25 \%$; $50 \%$; 75\% ; dan 100\%. Untuk konsentrasi $0 \%$; 25\% ; 50\%; 75\%; dan $100 \%$ angka TBA selama penyimpanan 4 hari tidak menunjukkan perbedaan yang terlalu mencolok, terutama hingga hari ketiga peyimpanan. Dari pengamatan aroma ikan pada hari ketiga tersebut masih layak. Hal ini menggambarkan kombinasi asap cair dan sari lemon cui bahan pangan cukup dilakukan dengan penambahan konsentrasi kombinasi asap cair dan sari lemon cui pada ikan cakalang dengan konsentrasi 10\%, karena pada konsentrasi tersebut daya hambat kombinasi asap cair dan sari lemon cui terhadap kerusakan oksidasi pada daging ikan cakalang selama 2 hari cukup efektif.

Tabel 3. Slop dari kombinasi ikan cakalang 10\%

\begin{tabular}{lr}
\hline Sampel & \multicolumn{1}{c}{ Slop } \\
\hline K & $10,28 \pm 0,02^{\mathrm{a}}$ \\
F0 & $6,41 \pm 0^{\mathrm{b}}$ \\
F1 & $7,52 \pm 0,04^{\mathrm{c}}$ \\
F2 & $7,05 \pm 0,09^{\mathrm{d}}$ \\
F3 & $6,87 \pm 0,02^{\mathrm{e}}$ \\
F4 & $7,85 \pm 0,03^{\mathrm{f}}$ \\
\hline
\end{tabular}

\section{KESIMPULAN}

Peroksidasi lipida dapat diukur dengan penentuan angka TBA. Berdasarkan hasil pengujian dan analisis data yang dilakukan, maka dapat disimpulkan bahwa kombinasi asap cair tongkol jagung dan sari lemon cui mengadung senyawa fenolik sebesar 93,94 $\mu \mathrm{g} / \mathrm{mL}$. Kombinasi asap cair tongkol jagung dan sari lemon cui memiliki aktivitas penangkal radikal bebas tertinggi sebesar 78,20\%. Kombinasi asap cair tongkol jagung dan sari lemon cui memiliki kandungn vitamin $\mathrm{C}$ tertinggi 2,921 ppm. Kombinasi asap cair dan sari lemon cui dengan konsentrasi $10 \%$ dapat menahan laju peroksidasi lipid pada daging ikan cakalang mentah selama 2 hari pada suhu $5^{\circ} \mathrm{C}$

\section{DAFTAR PUSTAKA}

Burda, S. \& Olezek, W. 2001.Antioxidant and antiradical activities of flavonoids. Journal of Agricultural and Food Chemistry. 49(1), 2774-2779.

Jacobs, M. 1987. The chemical analysis of foods and food products, 3rd Edition. D.Van Nostrand Companyu, Inc. New York.

Gaulejac, N.S-C., Provost, C. \& Vivas, N. 1998. Comparative study of polyphenol scavenging activities assessed by different methods. Journal of Agricultural and Food Chemistry. 47(2), 425-431.

Girard, J.P. 1992, Smoking in technology of meat and meat product dalam J.P. Girard and Morton (ed). Ellis Horwood Limited. New York.

Frankel, E.N. 2005. Lipida Oxidation. The Oily Press. Dundee, Scotland.

Halim M, Darmadji, P. \& Indrati, R. 2005. Fraksinasi dan identifikasi senyawa volatil asap cair cangkang sawit. Agritech. 25(3), 117-123.

Jeong, S.M., Kim, S.Y., Kim, D.R., Jo, S.C., Nam, K.C., Ahn, D.U \& Lee, S.C. 2004. Effect of heat treatment on the antioxidant activity of extracts from citrus peels. Journal of Agricultural and Food Chemistry. 52(11), 3389-3393.

Julkunen-Tito, R. 1985. Phenolic constituents in leaves of Northern Willows: Methods for the analysis of certain phenolics. Journal of Agricultural and Food Chemistry. 33(2), 213-217.

Kiay, N., Suryanto, E. \& Mamahit, L. 2011. Efek lama perendaman ekstrak kalamansi (Citrus microcarpa) terhadap aktivitas antioksidan tepung pisang goroho (Musa spp). Chemistry Progress. 3(1), 27-33.

Kumalaningsi, S., 2006. Antioksidan Alam. Trubus Agrisarana. Surabaya.

Lai, L-S. S-T. Chou, W-W. \& Chao. 2001. Studies on the antioxidative Actibities of Hsian-tsao (Mesona Procumbens Hemsl) leaf gum. Journal of Agricultural and Food Chemistry. 49, 963-968.

Mongkolsilp, S., Pongbupakit, I., Sae-Lee, N. \& Sitthithaworn, W. 2004. Radical scavenging activity and total phenolic content of medical plants used in primary health care. Jurnal of Pharmacy and Science. 9(1), 32-35.

Purba, B., Noor, Z. \& Darmadji, P. 2006. Daya hambat asap cair dalam pencegahan 
kerusakan oksidatif protein ikan tongkol putih (Thunus sp). Prosiding. Seminar Nasional PATPI, Yogyakarta 2-3 Agustus 2006.

Ramanathan, L. \& Das, N.P. 1992. Studies on the control of lipid oxidation in ground fish by some polyphenolic natural products. Journal of Agricultural and Food Chemistry. 40(1), 17-21.

Raharjo, S. 2006. Kerusakan oksidatif pada makanan. UGM Press, Yogyakarta.

Shahidi, F. \& Hong. C. 1991. Evaluation of malonaldehye as a marker of oxidative rancidity in meat products. Journal of Food Biochemistry. 15(2), 97-105.

Suryanto, E 2007. Singlet oxygen quencher dari ekstrak andaliman (Zanthoxylum acanthopodium DC.) untuk menghambat peroksidasi lipida pada ikan mas (Cyprinus carpio L.). SAINS. 1, 33-39.

Suryanto, E. 2012. Fitokimia Antioksidan. Putra Nusantara Media, Surabaya.
Suryanto, E., Momuat L., Taroreh M. \& Wehantouw, F. 2011. Pengaruh lemon kalamansi (Citrus microcarpa) terhadap komposisi kimia dan fitokimia antioksidan dari tepung pisang goroho (Musa spp). Chemistry Progress. 2(1), 11-19.

Mongan, J. Suryanto, E., Rumengan, I. 2011. Produksi dan fraksinasi asap cair dari limbah tongkol jagung untuk penghambatan peroksidasi lipida ikan laying (Decapterus russelli). Chemistry Progress. 2(1), 34-44.

Yen, G.C. \& Chen, H.Y. 1995. Antioxidant activity of various tea extracts in relation to their antimutagenicity. Journal of Agricultural and Food Chemistry. 43(1), 27-32.

Yen G.C. \& Duh, P.D. 1993. Antioxidative properties of methanolic extracts from peanut hulls. Journal of the American Oil Chemist's and Society. 70(6), 383-386. 